\title{
INTEGRASI YURIDIS NORMATIF DAN PSIKOLOGIS UNTUK MERAIH CINTA DAN BAHAGIA DALAM UNDANG-UNDANG PERKAWINAN DI INDONESIA
}

\author{
Durotun Nafisah* \\ Institut Agama Islam Negeri (IAIN) Purwokerto
}

Email: duroh.nafis@gmail.com

\begin{abstract}
:
The Marriage Law in Indonesia (UUP) is a positive legal rule in building a family. The UUP for example states that the purpose of marriage is to form a happy family, while the obligations of a husband and wife are to love, respect, respect and be loyal. Happiness, love, respect and loyalty are part of the psychological domain that cannot be achieved by merely reading normative juridical rules. Therefore a psychology study is needed to study the UUP. In addition to the psychological aspects, it is also important to study the UUP with a normative approach to see whether the UUP elaborates the normative values of the Qur'an as a source of Islamic teachings. The background of this paper is compiled with the aim of explaining the manifestations of psychological aspects formulated in the UUP so that it can be a reference for implementation in building families and analyzing the normative values of the Qur'an absorbed by the UUP. Therefore this UUP study was conducted with an integrated approach to normative and psychological juridical. This study also aims to develop family law with an integrative juridical psychological approach. The primary data sources used are the book of the Qur'aan by Quraysh Shihab, UUP and the book Motivation and Personality which examines happy psychology by Abraham H. Maslow and Triagular Theori of Love which discusses the theory of love in psychological perspective by Robert. J Steinberg as well as secondary sources related to research. The results of this study indicate that forming a happy family as a marriage goal is in harmony with Q.S. ar-Rum (30): 21 . While in a psychological perspective marital happiness can be achieved by a husband and wife can achieve if fulfilled the five basic human needs (hierarchy of needs) in humanistic psychology namely: physiological, security, social, appreciation and self-actualization needs. While husband and wife love is manifested in three aspects, namely attachment, caring and intimacy.
\end{abstract}

Keywords: Juridical, Normative, Psychological, Happy, Love, Marriage

\begin{abstract}
Abstrak:
Undang-Undang Perkawinan di Indonesia (UUP) merupakan aturan hukum positif dalam membangun keluarga. UUP menyatakan bahwa tujuan perkawinan adalah untuk membentuk keluarga yang bahagia, sementara kewajiban suami isteri diantaranya adalah saling mencintai, menghargai, menghormati dan setia. Bahagia, cinta, menghormati dan setia merupakan bagian dari domain psikologi yang tidak bisa diraih hanya dengan membaca aturan yuridis normative belaka. Oleh karenanya diperlukan kajian pskologi untuk menelaah UUP. Selain aspek psikologis tentu penting juga mengkaji UUP dengan pendekatan normative untuk melihat apakah UUP mengelaborasi nilai-nilai normative al-Qur'an sebagai sumber ajaran Islam. Dilatari oleh hal tersebut makalah ini disusun dengan tujuan menjelaskan manifestasi aspek-aspek psikologi yang diformulasikan dalam UUP sehingga bisa menjadi acuan implementasi dalam membangun keluarga dan menganalisis nilai-nilai normative al-
\end{abstract}

* Dosen Program Studi Hukum Keluarga Islam Fakultas Syariah Institut Agama Islam Negeri (IAIN) Purwokerto. 
Qur'an yang diserap oleh UUP. Oleh karenanya kajian UUP ini dilakukan dengan pendekatan integral yuridis normative dan psikologi. Kajian ini juga bertujuan untuk mengembangkan hukum keluarga dengan pendekatan integratif yuridis normatif psikologis. Sumber data primer yang digunakan adalah buku Pengantin al-Qur'an oleh Quraish Shihab, UUP dan buku Motivation and Personality yang mengkaji psikologi bahagia oleh Abraham H. Maslow dan Triagular Theori of Love yang membahas tentang teori cinta perspektif psikologi oleh Robert. J Steinberg serta sumber sekunder yang terkait dengan penelitian. Hasil penelitian ini menunjukkan bahwa membentuk keluarga bahagia sebagai tujuan perkawinan selaras dengan Q.S. ar-Rum (30): 21. Sedangkan dalam perspektif psikologis kebahagiaan perkawinan dapat diraih oleh suami isteri jika terpenuhi lima kebutuhan dasar manusia (hierarchy of needs) dalam psikologi humanistic yaitu: kebutuhan fisiologis, keamanan, sosial, penghargaan dan aktualisasi diri. Sedangkan cinta suami isteri termanifestasikan pada tiga aspek yaitu keterikatan (attachment), kepedulian (caring) dan keintiman (intimacy).

Kata Kunci: Yuridis, Normative, Psikologis, Bahagia, Cinta, Perkawinan,

\section{Pendahuluan}

Undang-Undang No.1 Tahun 1974 Tentang Perkawinan (UUP) merupakan hukum keluarga (hukum positif) ${ }^{1}$ yang mengatur tatacara dalam membangun keluarga Indonesia. UUP pasal 1 mendefinisikan perkawinan sebagai ikatan lahir batin antara seorang pria dan seorang wanita sebagai suami isteri dengan tujuan membentuk keluarga (rumah tangga) yang bahagia dan kekal berdasarkan ketuhanan Yang Maha Esa. Sementara kewajiban suami isteri dalam UUP pasal 33 wajib saling cinta mencintai, hormat-menghormati setia dan memberi bantuan lahir bathin yang satu kepada yang lain. ${ }^{2}$ Sangat jelas bahwa tujuan perkawinan hak dan kewajiban suami isteri sebagaimna yang diformulasikan dalam UUP tersebut tidak dapat terlaksana jika hanya membaca aturan yuridis saja. Karena ikatan batin, bahagia, cinta dan setia merupakan domain psikologi sehingga diperlukan pendekatan psikologi untuk menguak makna dan manifestasi dari beragam konsep tadi.

Dalam al-Qur'an hubungan suami isteri juga sangat sarat dengan nuansa psikologis. Allah menyatakan bahwa pernikahan adalah tali Allah yang menghubungkan dua hati agar memperoleh kedamaian, ketentraman hidup, cinta dan kasih sayang di antara suami isteri. Hal ini sebagaimana dalam surat ar-Rum (30): 21 Allah berfirman:

1 Positifisasi hukum adalah pemberlakuan hukum yang disahkan secara formalkonstitusional. Lihat A. Qadri Azizy, Eklektisisme Hukum Nasional, Kompetensi antara Hukum Islam dan Hukum Umum (Yogyakarta: Gama Media, 2002), hlm. 172-173. Hukum dibagi menjadi dua, pertama hukum positif yaitu hukum yang berlaku saat ini di suatu negara (ius constituendum). Kedua hukum yang dicita-citakan yaitu hukum yang hidup di masyarakat tetapi belum menjadi hukum positif (ius constitutum/the living law). Lihat Abdurrahman, Kompilasi Hukum Islam di Indonesia. (Jakarta: Akademi Pressindo, 1992). hlm. 9.

${ }^{2}$ Undang-Undang Republik Indonesia No. 1 Tahun 1974 Tentang Perkawinan.Lihat repo.unand.ac.id. Diakses 16-02-2017, Pk. 22.00 Wib. Tujuan perkawinan dan hak dan kewajiban suami isteri pasal 33 UUP sejalan dengan tujuan perkawinan dalam Q.S (30) ar-Rum: 21 yaitu membentuk keluarga yang bahagia, tenang dan damai (sakinah) diliputi dengan cinta dan kasih sayang. 


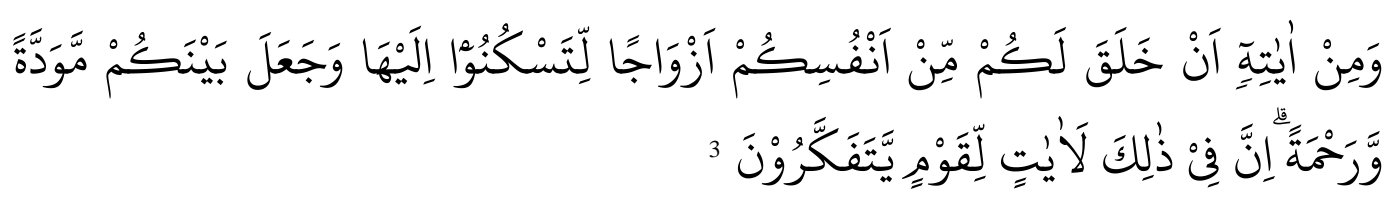

Pesan al-Qur'an ini secara selaras dengan UUP tentang tujuan perkawinan yaitu membentuk keluarga yang bahagia, ${ }^{4}$ tersirat semakin menguatkan bahwa pendekatan psikologi untuk membangun keluarga mutlak diperlukan. karena suami isteri sebagai pilar utama pembentuk keluarga memiliki keunikan psikologis. Mereka memiliki persepsi, cara berpilir, cara merasa dan cara merespon yang spesifik dan khas. Mereka juga memiliki kehendak yang sesuai dengan kondisi obyektif jiwanya. ${ }^{5}$ Psikologi humanistic Abraham Maslaw menawarkan konsep bahagia yang sangat relevan digunakan sebagai teori sekaligus pendekatan untuk mengkaji tujuan perkawinan yaitu membentuk keluarga yang bahagia sebagaimana yang disebutkan dalam UUP. Maslow, sebagai bapak psikologi humanistik, mengajukan teori "piramida kebutuhan" (hierarchy of needs) sebagai dasar peningkatan kebahagiaan manusia. Asumsinya bahwa untuk meraih kebahagiaan diperlukan adanya beberapa prasyarat yang harus dipenuhi. Prasyarat itu merupakan suatu kebutuhan asasi manusia yang jika dipenuhi akan menciptakan kebahagiaan. 6

\section{Manifestasi Bahagia Dalam UUP Perspektif Psikologi}

Di dalam UUP bahagia merupakan tujuan perkawinan, pada Bab I pasal 1 dinyatakan bahwa perkawinan ialah ikatan lahir bathin antara seorang pria dengan seorang wanita sebagai suami isteri dengan tujuan membentuk keluarga (rumah tangga) yang bahagia dan kekal berdasarkan Ketuhanan Yang Mahaesa. Dalam Kamus Besar Bahasa Indonesia, secara harfiah, kata 'bahagia' termasuk kata sifat yang diartikan sebagai keadaan atau perasaan senang tenteram dan bebas dari segala yang menyusahkan. Sedangkan 'kebahagiaan' berarti perasaan bahagia, kesenangan dan ketenteraman hidup lahir batin, keberuntungan, kemujuran yang bersifat lahir batin. ${ }^{7}$ Dalam American Webster Dictionary Kata 'bahagia' merupakan terjemahan untuk 'happy' yang menunjuk pada makna untung, mujur, riang, puas, gembira, tepat. 8 Sedangkan Ghâlib Ahmad Masrî dan Nâzif Jama' Adam, dalam bukunya Jalan Menuju Kebahagiaan, mendefinisikan kebahagiaan (happiness) sebagai suatu keadaan sejahtera yang ditandai dengan kelanggengan relatif,

3 Al-Qur'an dan Terjemahnya (Jakarta: Lajnah Pentashih Mushaf al Qur'an Departemen Agama RI, 1987) hlm. 644.

${ }^{4}$ Mengacu pada teori eklektisisme hukum maka sebagai hukum positif UUP mengadopsi tiga sistem hukum yaitu Islam, adat dan Barat. Dalam hal ini. yang diserap atau diadopsi adalah alQur'an. Lihat A. Qadri Azizy, Eklektisisme Hukum Nasional, Kompetensi antara Hukum Islam dan Hukum Umum (Yogyakarta: Gama Media, 2002), hlm. 172-173.

${ }^{5}$ Achmat Mubarok, Psikologi Keluarga (Malang: Madani, 2016), hlm. 2.

${ }^{6}$ Lihat uraiannya dalam Abraham H. Maslow, Motivation and Personality, (New York, NY: Harper \& Row, 1987), 15-22.

7 Pusat Pembinaan dan Pengembangan Bahasa, Kamus Besar Bahasa Indonesia, (Jakarta: Balai Pustaka, 1994), Hlm. 75.Dalam bahasa Arab, kata yang menunjuk makna bahagia adalah alsa'âdah, yang berarti lawan dari kecelakaan, lihat Ibn Manzûr, Lisân al-'Arab, Juz III, (Beirut: Dâr Sâdir, t.th.), Hlm. 213.

8 Philip D. Morehead, The New American Webster Dictionary, $4^{\text {th }}$ Edition, (New York: A Signet Book, 2001), Hlm. 365. 
dengan perasaaan yang sangat disukai secara dominan yang nilainya berurutan mulai dari hanya kepuasan sampai kepada kesenangan hidup yang mendalam dan intens serta dengan suatu hasrat yang alami agar keadaan ini berlangsung terus. ${ }^{9}$

Dari beberapa definisi bahagia di atas jelaslah bahwa bahagia merupakan konsep domain psikologis. Teori Maslow digunakan untuk mengelaborasi konsep kebahagiaan sebagaimana dalam UUP tersebut. Menurut Maslow untuk dapat meraih kebahagiaan seseorang harus memenuhi kebutuhan dasar manusia yang terdiri atas lima tingkatan, yaitu: (a) kebutuhan fisiologis, (b) kebutuhan keamanan, (c) kebutuhan cinta dan kepemilikan, (d) kebutuhan penghargaan, dan (e) kebutuhan aktualisasi diri.10

Berdasarkan teori piramida kebutuhan manusia yang dikemukakan Abraham Maslow, maka untuk membentuk keluarga yang bahagia maka suami isteri harus bisa memenuhi lima tingkat kebutuhan hidupnya. Kebutuhan tersebut berjenjang dari yang paling mendesak hingga yang akan muncul dengan sendirinya saat kebutuhan sebelumnya telah dipenuhi. Setiap pasangan suami isteri menginginkan dapat melalui tingkatan-tingkatan itu, namun hanya sedikit yang mampu mencapai tingkatan tertinggi dari piramida kebutuhan yang mencerminkan kebahagiaan ini. Kebahagiaan suami isteri sebagaimana dalam pasal 1 UUP berdasarkan berdasarkan teori psikologi humanistic Abraham Maslow termanifestasi menjdi lima tingkat kebutuhan yang secara berurutan dari yang paling rendah sampai yang tertinggi adalah sebagai berikut:

1. Kebutuhan Fisiologis(Physiological Needs)

Suami isteri bisa meraih kebahagian dalam kehidupan rumah tangganya jika kebutuhan primer meraka bisa terpenuhi. Kebutuhan primer itu adalah pertama, makan dan minum yang bergizi seimbang sesuai standar kesehatan. Kedua pakaian yang layak dan pantas sesuai kebutuhan dan kepantasan. Ketiga rumah atau tempat tinggal yang nyaman baik secara lingkungan biologis yakni udara dan air yang higeis maupun lingkungan social yakni aman dari tindakan criminal tetangga atau masyarakat sekitar.

Setiap orang tentunya mempunyai kebutuhan apalagi yang berhubungan dengan sandang, pangan, papan yang biasa disebut dengan kebutuhan primer, fisiologis, atau jasmaniah. Bagi keluarga modern perlu pula pemenuhan dalam hal kesehatan, pendidikan, rekreasi, transportasi dan komunikasi. Dalam keluarga tradisional digolongkan dalam kebutuhan sekunder. Kestabilan ekonomi turut andil dalam menentukan kebahagiaan keluarga, agar ekonomi stabil perlu diperlukan perencanaan anggaran keluarga dan keterbukaan/kejujuran dalam hal keuangan antar anggota keluarga.

Selama ini masyarakat dalam menganggap kebutuhan pangan, ayah lebih membutuhkan asupan gizi dari pada ibu dan anak-anak. Sebab ayahlah yang mencari nafkah, bekerja keras, dan lebih dari itu ayah sebagai kepala keluarga yang berhak mendapatkan pelayanan prima dibanding yang lain. Namun pandangan ini bertentangan dengan kebutuhan riil yang harus dipenuhi dimana pengabaian asupan gizi pada ibu usia subur terutama yang sedang hamil dan menyusui mengakibatkan ibu mengalami anemia dan reproduksi tidak sehat.

\footnotetext{
${ }^{9}$ Ghâlib Ahmad Masrî dan Nâzif Jama' Adam, Jalan Menuju Kebahagiaan, (Jakarta: Lentera, 1997), Hlm. 27.

${ }^{10}$ Lihat uraiannya dalam Abraham H. Maslow, Motivation and Personality, (New York, NY: Harper \& Row, 1987), 15-22.
} 
Bagi anak-anak dalam masa tumbuh kembang perlu mendapatkan perhatian agar proses pertumbuhan mereka dilalui dengan wajar, yang nantimya menjadikan ia anak yang kuat akan fisik dan mentalnya. Seluruh kebutuhan keluarga baik sandang, pangan, papan dirancang dengan mempertimbangkan kebutuhan berbeda teruama kebutuhan spesifik antara laki-laki dan perempuan karena mereka berbeda secara kodrati.

2. Kebutuhan Keamanan dan Keselamatan.

Setelah kebutuhan fisiologi terpenuhi maka suami isteri mesti memperoleh kebahagian tingkat berikutnya dengan terpenuhinya kebutuhan keamanan dan keselamatan.Dalam konteks ini suami merasa aman dan nyaman di samping isterinya, dan begitu pula isteri merasa aman dan nyaman di sisi suaminya. Aman dan selamat dari semua yang mengganggu, menyakiti ataupun membahayakan baik fisik maupun psikisnya Pendek kata terbebas dari semua bentuk kekerasan seperti bebes dari penindasan, bebas dari ancaman, bebas dari rasa sakit, bebas dari teror, dan semacamnya.

3. Kebutuhan Sosial.

Setelah kebutuhan yang kedua yaitu Kebutuhan Keamanan dan Keselamatan terpenuhi maka untuk menapaki kebahagiaan selanjutnya suami isteri harus bisa memenuhi kebutuhan social. Paling tidak ada tiga parameter bahwa kebutuhan social suami isteri terpenuhi. Pertama suami isteri bebas memiliki teman dan melakukan kegiatan bersama mereka. Kedua hubungan suami isteri dengan keluarga juga berjalan harmonis, dekat dan hangat, mereka saling berkomunikasi, saling mengunjungi dan melakukan kegiatan keluarga. Ketiga suami isteri saling mencintai, baik memikirkan diri sendiri sekaligus tergantung kepada pasangannya (defisiensi love) maupun bersifat tidak mementingkan diri sendiri dan peduli terhadap kebutuhan pasangannya, membantu pasangannya untuk mencapai aktualisasi diri (being love).

4. Kebutuhan Penghargaan.

Setelah berhasil memenuhi kebutuhan social maka suami isteri mesti bisa memenuhi kebutuhan penghargaan supaya kebahagiannya bertambah.Kebutuhan penghargaan dibagi menjadi dua. Pertama eksternal, dalam konteks ini suami isteri saling memuji dan memberi hadiah. Kedua internal, pribadi yang tidak memerlukan pujian atau penghargaan dari orang lain untuk merasakan kepuasan dalam hidupnya. Menurut penulis kebutuhan internal ini tidak sesuai dengan kenyataan kehidupan suami isteri yang selalu ingin memberi dan menerima pujian dan pemberian (hadiah atau semacamnya) sebagai salah satu yang membahagiakan

5. Kebutuhan Aktualisasi Diri.

Umumnya, kebutuhan aktualisasi diri akan muncul bila suami isteri merasa bahwa seluruh kebutuhan mendasarnya sudah terpenuhi. Pada hierarki ini, suami isteri saling mendukung dan membantu dalam mengejar ambisi, cita-cita atau hoby masing-masing. Mereka merasa bahagia jika pasangannya berhasil menjadi seseorang yang memiliki kemampuan lebih dalam bidang tertentu atau memperoleh kedudukan yang lebih baik dalam karier kedudukan social maupun bisa memenuhi apa yang menjadi hobinya. kualifikasi yang mengindikasikan karakteristik bahwa suami isteri telah beraktualisasi adalah sebagai berikut: a) Mereka memusatkan diri pada realitas (reality-centered), yakni suami isteri mampu melihat pasangannya apa adanya, objektif dan bebas dari bias. b) Mereka mampu memusatkan diri pada masalah (problem-centered). Suami isteri menyadari bahwa mesti ada problem rumah tangga oleh karenanya mereka berani menghadapinya bukan menghindari 
dan merekapun mencari solusi dan menyelesaikan problem itu secara bersamasama. c) Mereka menjalani kehidupan rumah tangga secara alami, suami isteri menjadi diri sendiri tidak menggantungkan diri kepada kedudukan keluarganya serta tidak berpura-pura atau membohongi pasangannya tentang dirinya (Spontanitas). d) Dalam ikatan perkawinan, suami isteri tetap memiliki otonomi pribadi, memiliki rasa puas diri yang tinggi terhadap apa yang diberikan kepada pasangannya dan yang diterima dari mereka. Suami isteri juga memiliki my time waktu untuk menikmati menyukai kesendirian dan menikmati hubungan persahabatan dengan sedikit orang namun bersifat mendalam. e) Penerimaan terhadap diri dan orang lain. Suami isteri bisa saling memberi penilaian tinggi pada individualitas dan keunikan diri sendiri pasangannya. Dengan kata lain suami isteri yang telah beraktualisasi diri lebih suka menerima pasangannya apa adanya ketimbang berusaha mengubah pasangannya. f) Rasa humor yang 'tidak agresif' (unhostile). Suami isteri lebih suka membuat lelucon yang menertawakan diri sendiri atau kondisi pasangannya humoris tanpa mengejek, ketimbang menjadikan dirinya atau pasangannya sebagai bahan lawakan dan ejekan. g) Kerendahatian dan menghargai orang lain (humility and respect). Suami isteri saling merendahkan diri, tidak sombong di hadapan pasangannya dan menghargai satu sama lain. h) Apresiasi yang segar (freshness of appreciation), yakni suami isteri mampu memberikan kreasi dan menciptakan sesuatu yang baru demi dan untuk pasangannya. i) Memiliki pengalaman spiritual yang disebut Peak experience. Suami isteri menempuh kehidupan spiritual atau taat mengamalkan ajaran agamanya.

\section{ManifestasiCinta Dalam UUP Perspektif Psikologi}

Kata cinta disebutkan di dalam UUPPasal 3.Salah satu kewajiban bersama suami isteri sebagaimana disebutkan dalam UUP Bab VI Hak dan Kewajiban Suami Isteri, Pasal 3 adalah saling cinta mencintai diantara suami isteri. ${ }^{11}$ Menurut profesor psikologi Universitas Hawaii, Elaine Hatfield, ada dua tipe dasar cinta, yaitu cinta kasih sayang (compassionate love) dan gairah cinta (passionate love). Berikut ini akan dikaji manifestasi cinta dalam UUP menurut psikolog Elaine

1. Cinta kasih sayang.

Suami isteri yang saling mencintai dalam kategori cinta kasih sayang ditandai dengan adanya saling keterikatan, saling menghormati, saling menghargai, saling peduli dan saling percaya satu sama lainnya.

2. Cinta yang dilandasi gairah (passionate love).

Dalam kategori cinta yang dilandasi gairah ini, cinta suami isteri ditandai dengan emosi yang intens, daya tarik seksual, kecemasan dan afeksi. Ketika cinta terbalaskan (reciprocated love), maka suami isteri merasa gembira dan bahagia. Namun jika cinta mereka terhadap pasangannya tidak terbalaskan (unreciprocated love), maka akan menyebabkan perasaan sedih, berkecil hati dan bahkan putus asa. Cinta yang didasari oleh gairah adalah fana, karena dipengaruhi fungsi

\footnotetext{
${ }^{11}$ Helen E. Fischer, Why Him Why Her? (Yogyakarta: Ufuk Press, 2011), hlm 47.
} 
fisiologis pada manusia. Seperti suami atau isteri merasa bergairah jika berada di depan pasangannya yang masih ada daya tarik seksualnya saja. ${ }^{12}$

3. Cinta yang ideal.

Cinta yang ideal yaitu cinta seorang suami terhadap isteri dan sebaliknya isteri terhadap suami adalah hubungan cinta yang menggabungkan antara kenyamanan dan kasih sayang dengan gairah itu sendiri. Sehingga hubungan antara pasangan akan bertahan lama dan terhindar dari masalah selingkuh maupun perceraian.

Cinta yang ideal dalam perspektif psikologis ini juga disampaikan oleh Psikolog Zick Rubin. Menurutnya cinta yang romantis terdiri dari tiga unsur, yakni : keterikatan (attachment), kepedulian (caring) dan keintiman (intimacy). Ketiga unsur cinta jika dimanifestasikan dalam cinta suami isteri adalah sebagai berikut. Pertama Keterikatan (attachment), suami isteri saling membutuhkan terpenuhinya hasrat seksual dari pasangannya. Mereka saling membutuhkan perhatian dan kontak fisik baik saling memesrai satu sama lain atau sampai hubungan intim.

Kedua, Kepedulian (caring). Dalam tahap cinta ini, suami isteri saling menghargai dan memberikan kebahagiaan antara satu dengan yang lainnya.Ketiga keintiman (intimacy). Dalam fase ini suami isteri sudah bisa berbagi pemikiran, keinginan dan perasaan antar mereka. ${ }^{13}$

\section{Landasan Normatif Konsep Bahagia dan Cinta Dalam UUP}

1. Bahagia.

Bahagia atau kebahagiaan' berarti perasaan bahagia; kesenangan dan ketenteraman hidup lahir batin, keberuntungan, kemujuran yang bersifat lahir batin. ${ }^{14}$ Dengan mencermati arti bahagia tersebut maka dalam konteks perkawinan dalil atau landasan normative yang paling sesuai untuk konsep bahagia yang merupakan tujuan perkawinan dalam UUP adalah Q.S. ar-Rum ayat 21:

"Dan di antara tanda-tanda kekuasaanNya ialah Dia menciptakan untukmu isteri-isteri dari jenismu sendiri. Supaya kamu cenderung dan merasa tenteram kepadanya. Dan dijadikanNya di antara kamu rasa kasih dan saying. Sesungguhnya pada yang demikian itu benar-benar terdapat tanda-tanda bagi kaum yang berpikir". ${ }^{15}$

${ }^{12}$ Robert J. Sternberg, “Triangulating Love”, in T. J. Oord ed. The Altruism Reader (2007)

${ }^{13}$ Rubin, Zick. 1970. Measurement of romantic love. Journal of Personality and Social Psychology dalam http://www.psychoshare.com/file-855/psikologi-dewasa/teori-cinta-4-teori-yangmenjelaskan-tentang-cinta.html Diakses Jumat 29-09-2013 Pk. 11.00 WIB

${ }_{14}$ Pusat Pembinaan dan Pengembangan Bahasa, Kamus Besar Bahasa Indonesia, (Jakarta: Balai Pustaka, 1994), Hlm. 75.Dalam bahasa Arab, kata yang menunjuk makna bahagia adalah alsa'âdah, yang berarti lawan dari kecelakaan, lihat Ibn Manzûr, Lisân al-'Arab, Juz III, (Beirut: Dâr Sâdir, t.th.), Hlm. 213.

${ }^{15}$ Departemen Agama RI, Al-Qur'an Dan Terjemahnya (Semarang: CV. Alwaah, 1989), Hlm. 644. 
Kata taskunu yang terdapat dalam Q.S. ar-Rum ayat 21 diterjemahkan dengan tenteram. Salah satu yang tercakup dalam muatan makna bahagia adalah tenteram. Menurut Quraish salah seorang pakar tafsir di Indonesia, salah satu tujuan pernikahan menurut al-Qur'an adalah untuk menciptakan sakinah, mawaddah, dan rahmah antara suami, istri dan anak-anaknya. ${ }^{16}$ Terkait dengan istilah sakinah, memunculkan beragama definisi. Di antaranya adalah Al-Isfahan (ahli fiqh dan tafsir) mengartikan sakînah dengan tidak adanya rasa gentar dalam menghadapi sesuatu. Menurut al-Jurjani (ahli bahasa), sakînah adalah adanya ketentraman dalam hati pada saat datangnya sesuatu yang tidak diduga, dibarengi satu nûr (cahaya) dalam hati yang memberi ketenangan dan ketentraman pada yang menyaksikannya, dan merupakan keyakinan berdasarkan penglihatan (ain al -yaqîn). ${ }^{17}$ Ada pula yang menyamakan sakînah itu dengan kata rahmah dan thuma'nî nah, artinya tenang, tidak gundah dalam melaksanakan ibadah. Dalam perkembangannya, kata sakiinah diadopsi ke dalam Bahasa Indonesia dengan ejaan yang disesuaikan menjadi sakinah yang berarti kedamaian, ketentraman, ketenangan, kebahagiaan.

Surat ar-Rum ayat 21 yang menjadi dalil atau landasan normative bahagia yang menjadi tujuan perkawinan dalam UUP itu, menginformasikan bahwa keberadaan seseorang sebagai pasangannya bertujuan untuk memperoleh ketenangan. "Ketenangan" dalam hal ini tentu saja berbeda dengan ketenangan yang dialami seseorang ketika ia sudah berada di dalam rumah setelah seharian mencari rezeki. Oleh karena itu, ketenangan sebagai tujuan dari keberadaan orang lain sebagai pasangannya adalah bersifat rohaniah atau biasa disebut dengan ketenangan jiwa. Artinya, secara fitrah laki-laki akan merasa tenang jiwanya dengan kehadiran seorang pendamping di sisinya, yakni istri. Begitu juga perempuan, ia akan merasa tenang dengan kehadiran laki-laki sebagai pendamping atau suaminya.

Term yaskunu dalam surat ar-Rum ayat 21 di atas dirangkai dengan kata "ilä" bukan dirangkai dengan kata "inda" yang berarti ketenangan atau kebahagiaan itu bersifat batin/rohani, bukan fisik. Di samping itu, susunan redaksi tersebut (yaskunu + ilā) juga mengindikasikan hilangnya kegoncangan dan gejolak jiwa yang sangat menggelisahkan. ${ }^{18}$ Dari penjelasan di atas, dapat disimpulkan bahwa kata sakinah dengan semua kata jadiannya, menunjukkan arti ketenangan dan ketenteraman, kebahagiaan baik fisik/jasmani maupun rohani/jiwa yang dirasakan oleh suami isteri karena keberadaan pasangannya. Yang pasti kata ini tidak digunakan kecuali untuk menggambarkan ketenteraman dan ketenangan setelah sebelumnya mengalami kegoncangan atau kegelisahan, baik yang bersifat rohaniah maupun jasmaniah.

Sakinah sebagai tujuan perkawinan tidak diungkapkan dengan kata benda (isim/noun), akan tetapi dengan bentuk kata kerja/fi'il/veb

\footnotetext{
${ }^{16}$ Quraish Shihab, Keluarga Sakinah, Dalam Jurnal Bimas Islam, Vol. 4 No.1, Tahun 2011, 4.

${ }^{17}$ Ibid

${ }^{18}$ Ibnu 'Asyūr, at-Tahrīr wat-Tanwīr, (t.t: t.p, t.th), jilid XIII: 3234
} 
(taskunulyaskunu), yang menunjukkan arti hudūs/ (kejadian baru) dan tajaddud (memperbaharui). Artinya, sakinah bukan sesuatu yang sudah jadi atau sekali jadi, namun ia harus diupayakan secara sungguh-sungguh (mujāhadah) dan terus menerus diperbaharui, sebab ia bersifat dinamis yang senantiasa timbul tenggelam. ${ }^{19}$ Dengan pengertian ini maka, sebuah perkawinan yang sakinah bukan berarti sebuah perkawinan yang tidak pernah ada masalah, sebab perkawinan bagaikan bahtera yang mengarungi lautan, dan setenang-tenangnya lautan pasti ada ombak. Demikian pula, suami isteri dalam mengarungi bahtera rumah tangga pasti ada problem. Mereka dengan penuh kesungguhan berusaha mengatasi masalah yang timbul, dengan didasarkan pada keinginan yang kuat suami isteri untuk menuju kepada terpenuhi ketenangan dan ketentraman jiwa mereka bersama.Dari beberapa penjelasan atau tafsir makna sakinah di atas semakin mempertegas bahwa tujuan perkawinan dalam UUP yaitu membentuk keluarga yang bahagia memiliki dalil atau landasan normative yaitu surat arRum ayat 21.

\section{Cinta}

Cinta atau saling mencintai antara suami isteri merupakan kewajiban bersama mereka sebagaimana disebutkan dalam pasal 34 ayat 1 UUP itu mengandung beberapa arti. Cinta dalam Kamus Besar Bahasa Indonesia memiliki beberapa arti, yaitu suka, kasih sayang dan rindu, Bahasa Arabnya cinta adalah mawaddah yang dalam bahasa Indonesia bisa diartikan cinta atau sebuah harapan. ${ }^{20}$ Kata mawaddah yang diartikan cinta ini juga ada pada AlQur'an surah Ar-Rum ayat 21:

"Dan diantara tanda-tanda kekuasaanNya ialah Dia menciptakan untukmu isteri-isteri dari jenismu sendiri. Supaya kamu cenderung dan merasa tenteram kepadanya. Dan dijadikanNya di antara kamu rasa kasih dan saying. Sesungguhnya pada yang demikian itu benar-benar terdapat tanda-tanda bagi kaum yang berpikir". ${ }^{21}$

Mahabbah berasal dari kata "habbah" yang berarti benih-benih/biji yang jatuh ke bumi di padang pasir. Mahabbah dikatakan berasal dari kata itu karena dia merupakan sumber kehidupan. Sebagaimana benih itu tersebar di gurun pasir, tersembunyi di dalam tanah, dihujani oleh terpaan angin, hujan dan sengatan matahari, disapu oleh cuaca panas dan dingin, benih-benih itu tidak rusak oleh perubahan musim, namun justru tumbuh berakar, berbunga dan berbuah. Demikian halnya cinta sejati, tak lapuk dengan sengatan mentari dan guyuran hujan, tak lekang oleh perubahan musim dan tak hancur berantakan oleh terpaan angin.

Berdasarkan ayat di atas, maka sangat jelas landasan normative cinta suami isteri adalah surat ar-Rum ayat 21 . Terdapat dua cinta yang mesti dicapai

\footnotetext{
${ }^{19} \mathrm{Ibid}$

${ }^{20}$ Kata mawaddah juga sudah diadopsi ke Bahasa Indonesia menjadi mawadah yang berarti kasih sayang

${ }^{21}$ Departemen Agama RI, Al-Qur'an Dan Terjemahnya (Semarang: CV. Alwaah, 1989), Hlm. 644.
} 
dalam pernikahan, yaitu cinta mawaddah dan cinta rahmah. Mawaddah adalah cinta yang terwujud dari dorongan untuk memenuhi kebutuhan biologis sebagai fitrah insani. Dengan demikian cinta suami isteri yang diekspresikan karena dorongan biologis dengan saling bermesraan dan atau berhubungan badan merupakan fitrah insani yang diperbolehkan secara Qur'ani. ${ }^{22}$ Sedangkan menurut pakar Tafsir Quraisy Shihab Mawaddah adalah kelapangan dada dan kehendak jiwa dari kehendak buruk. Mawaddah mengandung pengertian filosofis adanya dorongan batin yang kuat dalam diri sang pencinta untuk senantiasa berharap dan berusaha menghindarkan orang yang dicintainya dari segala hal yang buruk, dibenci dan menyakitinya. ${ }^{23}$. Cinta mawaddah ini jika dimplementasi pada cinta suami isteri maka mereka dalam mengekspresikan cinta kepada pasangannya selalu menghindarkan pasangannya dari segala hal yang buruk, menghilangkan semua yang dibenci pasangannya dan melenyapkan apa saja bisa menyakitkan pasangannya

Term mawaddah, dalam konteks ayat ini, mengacu pada penjelasan sebelumnya, adalah mengandung dua makna sekaligus yaitu mahabbah (cinta) dan tamannī kaunihi (keinginan untuk mewujudkan). Atau dengan kata lain, perasaan saling mencintai itulah yang mendorong suami isteri untuk saling mendekat. Oleh karena itu, mawaddah bukanlah cinta biasa yang terkadang timbul tenggelam, bahkan pupus sama sekali. Mawaddah, meminjam istilah M. Quraish Shihab, adalah "cinta plus". Sebab, ketika seseorang yang sudah dipenuhi perasaan mawaddah, maka cintanya akan sangat kukuh dan tidak mudah putus, sebab hatinya senantiasa lapang dan kosong dari kehendak buruk. ${ }^{24}$ Begitu pula cinta suami isteri mestinya kuat, kokoh dan tidak mudah goyah karena terbaan gossip atau cobaan. Justru ujian dan cobaan itu akan menguatkan dan meneguhkan cinta mereka. Di samping itu suami isteri tidak ada kehendak buruk terhadap pasangannya, bersedia melapangkan dada serta memaafkan kesalahan pasangannya.

Wujud cinta suami isteri menurut surat ar-Rum ayat 21 yang kedua adalah Rahmah. Kata rahmah, setelah diadopsi dalam Bahasa Indonesia ejaannya disesuaikan menjadi rahmat yang berarti kelembutan hati dan perasaan empati yang mendorong seseorang melakukan kebaikan kepada pihak lain yang patut dikasihi dan disayangi. Karena itu, implementasi cinta rohmah dalam kehidupan suami isteri akan berbuah. Menurut Asyfahānī, kata rahmah mengandung dua arti, kasih sayang (riqqah) dan budi baik/murah hati (ihsān). ${ }^{25}$ Kata rahmah yang berarti kasih sayang (riqqah) adalah dianugerahkan oleh Allah kepada setiap manusia. Artinya, dengan rahmat Allah tersebut manusia akan mudah tersentuh hatinya jika melihat pihak lain yang lemah atau merasa iba atas penderitaan

${ }^{22}$ Asy-Syaukani, Fat al-Qadir(Bairut: Mustofa al-Babi al-Halabi, 1990) IV : 219.

${ }^{23}$ Quraish Shihab, Keluarga Sakinah, Dalam Jurnal Bimas Islam, Vol. 4 No.1, Tahun 2011, 4-6.

${ }^{24}$ M. Quraish Shihab, Pengantin Al-Qur'an, (Jakarta: Lentera Hati, 2007), cet ke-3, hlm. 88

${ }^{25}$ Al-Ashfahānī, al-Mufradāt fì Gharībil-Qur'ān, ditahqiq oleh MuhammadSayyid al-Kailanī, (Beirut:Dārul-Ma'rifah, t.th) hlm. 236. 
orang lain. ${ }^{26}$ Dari cinta rahmah inilah rasa cinta yang mendalam mendorong suami isteri untuk bertekad melakukan yang terbaik dan berkorban untuk pasangannya. Di sinilah perkawinan yang bertujuan membentuk keluarga yang sakinah akan senantiasa diliputi dengan rahmah, yaitu kondisi psikologis yang mendorong seseorang untuk melakukan yang terbaik kepada pihak lain..$^{20}$

Ada juga yang memahami rahmah adalah sesuatu yang menumbuhkan sifat kasihan dan simpati atas dasar kekerabatan dan kasih sayang. Pendapat yang lain menyatakan bahwa rahmah adalah sesuatu yang mendorong seseorang melakukan perbuatan yang melahirkan rida Allah. ${ }^{21}$ Dari beberapa penjelasan tersebut dapat disimpulkan bahwa 21 implementasi cinta suami isteri dalam UUP yang memperoleh justifikasi surat ar-Rum ayat adalah terbangunnya sebuah perkawinan yang dirahmati, indikasinya adalah kedua belah pihak berusaha secara sungguh-sungguh mencintai dengan tulus terhadap pasangannya masing-masing, serta memperlakukan pasangannya dengan perlakuan yang baik, bahkan yang terbaik, serta keduanya berusaha melakukan hal-hal yang bisa mendatangkan rida Allah. Untuk itu masing-masing pihak, suami-istri saling bantu-membantu, dan dukung-mendukung demi terpenuhinya kebahagiaan, kedamaian, cinta dan kasih sayang dalam perkawinan mereka.

\section{Penutup}

Untuk memahami konsep yang bernuansa psikologis dalam aturan yuridis yaitu UUP seperti bahagia sebagai tujuan perkawinan (pasal 1) dan cinta serta aspek psikologis lainnya sebagai kewajiban suami isteri (pasal 33) membutuhkan pendekatan integrative yaitu yuridis, normative, dan psikologis. Pendekatan yuridis diperlukan karena UUP merupakan aturan hukum positif dalam membangun keluarga. Pendekatan psikologis dibutuhkan karena tujuan perkawinan yaitu untuk membentuk keluarga yang bahagia, kewajiban suami isteri saling mencintai, menghargai, menghormati dan setia adalah sebagian dari domain psikologi yang tidak bisa diraih hanya dengan membaca aturan yuridis normative belaka, namun mesti dijelaskan manifestasi aspek-aspek psikologi yang diformulasikan dalam UUP sehingga bisa menjadi acuan implementasi dalam membangun keluarga. Sedangkan pendekatan normative digunakan untuk melihat apakah UUP mengelaborasi nilai-nilai normative al-Qur'an sebagai sumber ajaran Islam.

Hasil penelitian ini menunjukkan bahwa membentuk keluarga bahagia sebagai tujuan perkawinan selaras dengan Q.S. ar-Rum (30): 21. Sedangkan dalam perspektif psikologis kebahagiaan perkawinan dapat diraih oleh suami isteri dapat meraih jika terpenuhi lima kebutuhan dasar manusia (hierarchy of needs) dalam psikologi humanistic yaitu 1) kebutuhan fisiologis yakni kebutuhan

26 Shihab, Pengantin Al-Qur'an, (Jakarta: Lentera Hati, 2007), cet ke-3, hlm. 88 
primer suami isteri yaitu makan, minum dan tempat tinggal tercukupi secara komprehensif. 2) kebutuhan keamanan dan kesehatan baik secara fisik (biologis), sosiologis maupun psikologis. 3) kebutuhan sosial yang mencakup tiga aspek yaitu suami isteri bebas memiliki teman dan melakukan kegiatan bersama mereka, hubungan suami isteri dengan keluarga juga berjalan harmonis, dekat dan hangat, saling berkomunikasi, saling mengunjungi dan melakukan kegiatan keluarga serta suami isteri saling mencintai. 4) kebutuhan penghargaan yaitu suami isteri saling memuji dan memberi hadiah. 5) kebutuhan aktualisasi diri yaitu suami isteri saling mendukung dan membantu dalam mengejar ambisi, cita-cita atau hoby masing-masing. Sedangkan cinta suami isteri termanifestasikan pada tiga aspek yaitu keterikatan (attachment), kepedulian (caring) dan keintiman (intimacy).

\section{Daftar Pustaka}

Abdurrahman, Kompilasi Hukum Islam di Indonesia.,Jakarta: Akademi Pressindo, 1992. Al-Ashfahānī, al-Mufradāt fi Gharībil-Qur'ān, ditahqiq oleh Muhammad Sayyid alKailanī, Beirut: Dārul-Ma'rifah, t.th.

Asy-Syaukani, Fat al-Qadir. Bairut: Mustofa al-Babi al-Halabi, 1990.

Azizy, A. Qadri. Eklektisisme Hukum Nasional, Kompetensi antara Hukum Islam dan Hukum Umum, Yogyakarta: Gama Media, 2002.

Departemen Agama RI, Al-Qur'an Dan Terjemahnya, Semarang: CV. Alwaah, 1989. Fischer, Helen E. Why Him Why Her?, Yogyakarta: Ufuk Press, 2011.

Ibn Manzûr, Lisân al-'Arab, Juz III, Beirut: Dâr Sâdir, t.th.

Ibnu 'Asyūr, at-Tahrīr wat-Tanwīr, t.t: t.p, t.th.

Maslow, Abraham H. Motivation and Personality, New York, NY: Harper \& Row, 1987.

Masrî, Ghâlib Alhmad dan Nâzif Jama' Adam, Jalan Menuju Kebahagiaan, Jakarta: Lentera, 1997.

Morehead, Philip D. The New American Webster Dictionary, $4^{\text {th }}$ Edition, New York: A Signet Book, 2001.

Mubarok, Achmat. Psikologi Keluarga, Malang: Madani, 2016.

Pusat Pembinaan dan Pengembangan Bahasa, Kamus Besar Bahasa Indonesia, Jakarta: Balai Pustaka, 1994.

Rubin, Zick. 1970. Measurement of romantic love. Journal of Personality and Social Psychology dalam http://www.psychoshare.com/file-855/psikologidewasa/teori-cinta-4-teori-yang-menjelaskan-tentang-cinta.html

Shihab, M. Quraish. Pengantin Al-Qur'an, Jakarta: Lentera Hati, 2007.

Shihab, Quraish. "Keluarga Sakinah", Dalam Jurnal Bimas Islam, Vol. 4 No.1, Tahun 2011

Sternberg, Robert J. "Triangulating Love", in T. J. Oord ed. The Altruism Reader, 2007. 